\title{
KETIDAKNYAMANAN FISIK DAN PSIKOLOGIS PADA IBU HAMIL TRIMESTER III DI WILAYAH PUSKESMAS BERBAH SLEMAN DAERAH ISTIMEWA YOGYAKARTA
}

\author{
Sri Wulandari ${ }^{1}$ Nonik Ayu Wantini ${ }^{2}$ \\ Fakultas Ilmu Kesehatan Universitas Respati Yogyakarta \\ (wulanrayya2@gmail.com)
}

\begin{abstract}
ABSTRAK
Latar Belakang:Wanita dalam masa kehamilan banyak mengalami perubahan dalam dirinya, baik secara fisik maupun psikologisnya. Perubahan terus terjadi selama 9 bulan kehamilan. Ketidaknyamanan fisik dan psikis sudah sejak awal dirasakan selama kehamilan. Kemudian ditambah dengan bayangan mengenai proses persalinan dan bagaimana bayinya kelak setelah lahir. Sekitar $70 \%$ dari ibu hamil mengalami sakit pinggang low back pain (LBP)yang mungkin terjadi sejak awal trimester, dimana puncak kejadian LBP tersebut terjadi pada ibu hamiltrimester II dan III kehamilan. Kecemasan atau psikologis ibu dalam menghadapi proses persalinan salah satu dari ketidaknyamanan yang dialami ibu hamil.

Tujuan: Penelitian ini bertujuan untuk mengetahui ketidaknyamanan fisik dan psikologis pada ibu hamil trimester III di wilayah Puskesmas Berbah Sleman DIY.

Metode penelitian: Jenis penelitian survei analitik dengan rancangan cross sectional. Penelitian dilaksanakan di Wilayah Puskesmas Berbah Sleman DIY. Teknik pemilihan sampel menggunakan purposive sampling dengan jumlah sampel 63 orang ibu hamil TM III, jenis data adalah data primer, instrumen kuesioner. Analisis uji statistik menggunakan Kendal Tau.

Hasil penelitian: menunjukan bahwa umur responden adalah usia reproduktif (20-35 tahun) sebanyak $84,10 \%$, pendidikan tinggi sebanyak $46 \%$, ibu bekerja sebanyak $52,40 \%$, riwayat persalinan spontan sebanyak $46 \%$, ketidanyamanan fisik kehamilan trimester III adalah sedang sebanyak $77,80 \%$, ketidaknyamanan psikologi kehamilan trimester III adalah sedang sebanyak 46\%, kecemasan ibu hamil trimester III akibat pandemi Covid-19 sedang sebanyak 52,40\%, ada hubungan ketidaknyamanan fisik dan psikologis pada ibu hamil trimester III (pvalue $=0,012$ ), ada hubungan antara ketidaknyamanan fisik dan kecemasan akibat pandemi Covid-19 pada ibu hamil trimester III ( $\mathrm{p}$-value $=0,013$ ).

Kesimpulan: ada hubungan antara ketidaknyamanan fisik dan psikologis pada ibu hamil trimester III, ada hubungan antara ketidaknyamanan fisik dan kecemasan akibat pandemi Covid-19 pada ibu hamil trimester III di wilayah Puskesmas Berbah Sleman DIY.
\end{abstract}

Kata Kunci:Ketidaknyamanan Fisik, Ketidaknyamanan Psikologis, Hamil Trimmester III. 


\title{
Physical and Psychological Discomfort in Pregnant Woman Trimester III in the Puskesmas Berbah Area SlemanYogyakarta Special Region
}

\begin{abstract}
Background: Women who are in pregnancy experience a lot of changes in themselves, both physically and psychologically. Changes continue to occur during the 9 months of pregnancy. Physical and psychological discomfort can be felt from the beginning during pregnancy. Then added with an overview of the labor process and how the baby will be after birth. Approximately $70 \%$ of pregnant women experience low back pain (LBP) that may occur since the early trimester, where the peak incidence of LBP occurs in pregnant women in the second and third trimesters of pregnancy. Anxiety or psychological mothers in facing the childbirth process is one of the discomforts experienced by pregnant women.
\end{abstract}

The Aim: This study aims to determine the physical and psychological discomfort of third trimester pregnant women in the PuskesmasBerbahSleman DIY.

Method: This was an analytic survey research with a cross sectional design. The research was conducted in the area of PuskesmasBerbahSleman Yogyakarta. The number of samples is 63 TM III pregnant women, the type of data is primary data, questionnaire instrument. Statistical test analysis using Kendal Tau.

Results: shows that the age of the respondents is reproductive age (20-35 years) as much as $84.10 \%$, higher education as much as 46\%, working mothers as much as $52.40 \%$, a history of spontaneous labor as much as $46 \%$, physical discomfort in the third trimester of pregnancy is moderate. as much as $77.80 \%$, the psychological discomfort of pregnancy in the third trimester was moderate as much as 46\%, the anxiety of the third trimester pregnant women due to the Covid19 pandemic was $52.40 \%$, there was a relationship between physical and psychological discomfort in the third trimester of pregnant women ( $p$-value $=$ 0.012 ), there is a relationship between physical discomfort and anxiety due to the Covid-19 pandemic in third trimester pregnant women ( $p$-value $=0.013)$.

Conclusion: there is a relationship between physical discomfort between the psychology of pregnant women in the third trimester, there is a relationship between physical discomfort and anxiety due to the Covid-19 pandemic in third trimester pregnant women in the PuskesmasBerbahSleman DIY.

Keywords:Physical discomfort, Psychological discomfort, Third Trimester Pregnancy 


\section{PENDAHULUAN}

Masa kehamilan dimulai dari hasil konsepsi sampai lahirnya janin. Lamanya kehamilan normal adalah 280 hari yang dimana dihitung dari hari pertama haid terakhir(Saifudin,2008). Menurut Kementrian Kesehatan Reprublik Indonesia tahun 2017 untuk jumlah ibu hamil di Provinsi D.I Yogyakarta 59.617 orang. Menurut laporan Profil Data Kesehatan Indonesia tahun 2015, diwilayah Provinsi Jawa Tengah jumlahnya ada 314.492 ibu hamil mengalami nyeri pada punggung bawah (pinggang)(Intarti, 2007). Menurut penelitian yang dilakukan (Fitriani, 2018), sekitar 70\% dari ibu hamil mengalami sakit pinggang low back pain (LBP)yang mungkin terjadi sejak awal trimester, dimana puncaknya pada trimester II dan III kehamilan.

Wanita dalam masa kehamilan banyak mengalami perubahan dalam dirinya, baik secara fisik maupun psikologisnya. Ketidaknyamanan fisik sudah sejak awal dirasakan selama kehamilan. Kemudian ditambah dengan bayangan mengenai proses persalinan dan bagaimana bayinya kelak setelah lahir (Fauziah, 2017) . Nyeri pinggang saat hamil biasanya terjadi karena adanya peregangan tulang-tulang, terutama didaerah pinggang yang sesuai dengan bertambahnya usia kehamilan(Andarmoyo, 2013). Menurut(Rosdiani dkk, 2014) Nyeri pinggang pada ibu hamil dapat dikurangi dengan olahraga,

Ketidaknyamanan kehamilan pada ibu hamil menurut (Prawirohardjo, 2017), Ketidaknyamanan TM I antara lain Ngidam Keputihan, Rasa mual muntah, Pusing/sakit kepala, Kelelahan, Insomnia, Sering miksi, Ketidaknyamanan TM II dan III, Haemoroid, Konstipasi, Varises, Gatal-gatal, Nyeri ulu hati, Perut kembung, Nyeri pinggang (punggung bawah).

Menurut (Kusmiyati, 2010)Pada trimester I terjadi peningkatan hormon esterogen dan progesteron yang mempengaruhi perubahan pada fisik sehingga banyak ibu hamil yang merasakan kekecewaan, penolakan, kecemasan dan kesedihan. Pada trimester II ibu hamil merasa sudah baik dan terbebas dari rasa ketidaknyamanan yang telah dialami pada trimester I. Pada trimester ketiga, ibu hamil akan mengalami perasaan yang tidak menyenangkan ketika bayi tidak lahir tepat pada waktunya.

Merebaknya pandemi Covid-19 di Indonesia selain berdampak terhadap perekonomian, pendidikan dan sosial masyarakat, juga berdampak pada pelayanan kesehatan seperti berkurangnya ketersediaan layanan KIA dan KB, berkurangnya akses terhadap layanan kesehatan, kurangnya layanan yang tepat sesuai kebutuhan dan komprehensif dan meningkatnya resiko infeksi pada tenaga kesehatan dan masyarakat. Semua itu mengakibatkan ketidaknyamanan pada masyarakat terutama ketidaknyamanan psikologis karena merasa cemas.

Peran tenaga kesehatan sangat dibutuhkandi masa pandemi. Tanpa mengurangi kualitas pelayanan KIA dan KB, Ikatan Bidan Indonesia merekomendasikan pelayanan KIA dan KB selama pandemi seperti menyediakaan tempat cuci tangan, memastikan semua peralatan steril, pelayanan 
dilakukan dengan membuat janji terlebih dahulu, bidan harus menerapkan prosedur pencegahan Covid-19, memastikan bidan menggunakan APD lengkap, lakukan skrening terhadap faktor resiko infeksi Covid-19 (Nurjasmi, 2020)

Jumlah Ibu hamil trimester III diwilayah kerja Puskesmas Berbah Sleman tahun 2019 adalah 832 orang. Puskesmas Berbah mempunyai program kelas ibu hamil kegiatan dilaksanakan setiap bulannya. Banyak jenis kegiatan yang diberikan seperti senam hamil, penyuluhan informasi seputar program Puskesmas. Sejak adanya pandemi Covid-19, kegiatan kelas ibu hamil sementara ditiadakan, dan ibu hamil seminimal mungkin datang untuk periksa ANC. Oleh karena itu tujuan dari penelitian ini adalah mengetahui ketidaknyamanan fisik dan psikologis serta kecemasan saat pandemi pada ibu hamil trimester III.

\section{METODE PENELITIAN}

Penelitian ini merupakan penelitian survei analitik dengan pendekatan atau desain cross sectional. Adapun lokasi penelitian adalah di wilayah kerja Puskesmas Berbah Sleman Yogyakarta. Waktu pengambilan data mulai bulan September - November 2020. Populasi dalam penelitian ini adalah ibu hamil trimester III. Jumlah responden adalah 63 orang. Teknik pengambilan sample dengan menggunakan purposive sampling. Teknik pengumpulan data dengan kuesioner. Analisis uji statistik univariat dan bivariat dengan Kendal Tau. Penelitian ini telah sesuai dengan prinsip-prinsip etik, yang dinyatakan sudah memenuhi syarat etik oleh Komisi Etik Fakultas Ilmu Kesehatan, Universitas Respati Yogyakarta dengan surat kelaikan etik

\section{Hasil}

\section{HASIL DAN PEMBAHASAN}

1. Analisis Univariat

Tabel 1. Distribusi Frekuensi Karakteristik Ibu Hamil Trimester III

\begin{tabular}{clcc}
\hline No & \multicolumn{1}{c}{ Karakteristik } & Jumlah (n) & $\%$ \\
\hline 1 & Usia & 53 & \\
& Usia reproduktif (20-35 tahun) & 10 & 15,90 \\
& Usia berisiko (> 35 tahun) & & \\
2 & Pendidikan & 7 & 11,10 \\
& Dasar & 27 & 42,90 \\
& Menengah & 29 & 46,00 \\
& Tinggi & & \\
3 & Pekerjaan & 30 & 47,60 \\
& IRT & 33 & 52,40 \\
& Bekerja & & \\
Status Kehamilan & 20 & 31,70 \\
& Primigravida (1) & 41 & 65,10 \\
& Multigravida (2-4) & 2 & 3,20 \\
Grandemultigravida (>5) & Jumlah janin & & 95,20 \\
& Tunggal & 60 & 4,80
\end{tabular}


6 Jumlah anak

1

2-4

$\begin{array}{ll}22 & 34,90 \\ 31 & 49,20\end{array}$

Riwayat Persalinan

15,90

Belum pernah melahirkan $\quad 20 \quad 31,70$

Spontan

46,00

Sectio Caesarea (SC)

20,60

Spontan dan SC

8 Riwayat Komplikasi Persalinan

1

$\begin{array}{lll}\text { Belum pernah melahirkan } & 20 & 31,70\end{array}$

Tidak ada komplikasi $\quad 34 \quad 54,00$

$\begin{array}{lll}\text { Ada komplikasi } & 9 & 14,30\end{array}$

$9 \quad$ Kebiasaan olahraga

Rutin (1-2 x/minggu @30 menit) $\quad 38 \quad 60,30$

$\begin{array}{lll}\text { Tidak Pernah } & 25 & 39,70\end{array}$

Total masing-masing karakteristik

63

100

Berdasarkan tabel 1 di ketahui bahwa usia ibu hamil trimester III sebagian besar usia reproduktif (20-35 tahun) sebanyak $84,10 \%$, paling banyak berpendidikan tinggi (46\%), sebagian besar ibu bekerja $(52,40 \%)$, mayoritas status kehamilan multigravida (65\%), mayoritas janin yang di kandung adalah tinggal $(95,20 \%)$, paling banyak memiliki jumlah anak 1 $(49,20 \%)$, paling banyak pernah melahirkan secara spontan (46\%), sebagian besar tidak ada komplikasi persalinan (54\%) dan sebagian besar rutin melakukan olahraga $(60,30 \%)$.

Tabel 2 Distribusi frekuensi Ketidaknyamanan Fisik Kehamilan trimester III

\begin{tabular}{|c|c|c|c|}
\hline No & Ketidaknyamanan Fisik & Jumlah (n) & $\%$ \\
\hline 1 & Ringan & 10 & 15,90 \\
\hline 2 & Sedang & 49 & 77,80 \\
\hline 3 & Berat & 4 & 6,30 \\
\hline & Total & 63 & 100,00 \\
\hline
\end{tabular}

Berdasarkan tabel 2 diketahui bahwa ketidaknyamanan fisik ibu hamil trimester III 77,80\% dalam kategori sedang.

Tabel 3 Distribusi frekuensi Jenis ketidaknyamanan Kehamilan trimester III

\begin{tabular}{clcc}
\hline No & \multicolumn{1}{c}{ Jenis Ketidaknyamanan } & Jumlah (n) & $\%$ \\
\hline 1 & Buang Air Kecil & 1 & 1,60 \\
& Tidak Pernah & 3 & 4,80 \\
& Jarang & 13 & 20,60 \\
& Kadang-kadang & 46 & 73,00 \\
& Sering & & \\
2 & Sembelit/Susah BAB & 20 & 31,70 \\
& Tidak Pernah & 22 & 34,90 \\
& Jarang & 18 & 28,60 \\
& Kadang-kadang & 3 & 4,80 \\
Sering & & \\
Kram pada kaki & 18 & 28,60 \\
& Tidak Pernah & 18 & 28,60 \\
& Jarang & 21 & 33,33
\end{tabular}




\begin{tabular}{|c|c|c|c|}
\hline & \multicolumn{3}{|l|}{ Sering } \\
\hline & Pusing & 6 & 9,50 \\
\hline \multirow{4}{*}{4} & Tidak Pernah & 21 & 33,33 \\
\hline & Jarang & 25 & 39,70 \\
\hline & Kadang-kadang & 15 & 23,80 \\
\hline & Sering & 2 & 3,20 \\
\hline \multirow[t]{5}{*}{5} & Bengkak pada kaki & & \\
\hline & Tidak Pernah & 48 & 76,20 \\
\hline & Jarang & 8 & 12,70 \\
\hline & Kadang-kadang & 5 & 7,90 \\
\hline & Sering & 2 & 3,20 \\
\hline \multirow[t]{5}{*}{6} & Susah Tidur & & \\
\hline & Tidak Pernah & 7 & 11,10 \\
\hline & Jarang & 15 & 23,80 \\
\hline & Kadang-kadang & 27 & 42,90 \\
\hline & Sering & 14 & 22,22 \\
\hline \multirow[t]{5}{*}{7} & Kesemutan pada jari tangan dan kaki & & \\
\hline & Tidak Pernah & 19 & 30,20 \\
\hline & Jarang & 19 & 30,20 \\
\hline & Kadang-kadang & 17 & 27,00 \\
\hline & Sering & 8 & 12,70 \\
\hline \multirow[t]{5}{*}{8} & Sesak Nafas & & \\
\hline & Tidak Pernah & 19 & 30,20 \\
\hline & Jarang & 20 & 31,70 \\
\hline & Kadang-kadang & 19 & 30,20 \\
\hline & Sering & 5 & 7,90 \\
\hline \multirow[t]{5}{*}{9} & Nyeri Pinggang & & \\
\hline & Tidak Pernah & 5 & 7,90 \\
\hline & Jarang & 11 & 17,50 \\
\hline & Kadang-kadang & 29 & 46,00 \\
\hline & Sering & 18 & 28,60 \\
\hline \multirow[t]{5}{*}{10} & Nyeri Punggung Atas dan Bawah & & \\
\hline & Tidak Pernah & 11 & 17,50 \\
\hline & Jarang & 12 & 19,00 \\
\hline & Kadang-kadang & 27 & 42,90 \\
\hline & Sering & 13 & 20,60 \\
\hline \multirow[t]{5}{*}{11} & Masalah pada gigi dan gusi & & \\
\hline & Tidak Pernah & 32 & 50,80 \\
\hline & Jarang & 19 & 30,20 \\
\hline & Kadang-kadang & 9 & 14,30 \\
\hline & Sering & 3 & 4,80 \\
\hline \multirow[t]{6}{*}{12} & Mudah lelah & & \\
\hline & Tidak Pernah & 1 & 1,60 \\
\hline & Jarang & 9 & 14,30 \\
\hline & Kadang-kadang & 29 & 46,00 \\
\hline & Sering & 24 & 38,10 \\
\hline & Total masing-masing karakteristik & 63 & 100 \\
\hline
\end{tabular}

Berdasarkan tabel 3 diketahui jenis ketidaknyamanan yang dialami ibu hamil trimester III adalah mayoritas sering BAK 73\%, ibu jarang mengalami sembelit 34,90\%, kadang-kadang kram pada kaki 33,33\%, ibu jarang pusing sebanyak 39,70\%, mayoritas ibu tidak pernah mengalami bengkak pada kaki $76,20 \%$, ibu hamil trimester III kadang-kadang mengalami susah tidur $42,90 \%$, kesemutan pada jari kaki dan tangan 
jarang dan tidak pernah dialami ibu hamil sebanyak 30,20\%, 31,70\% ibu hamil jarang sesak nafas, sebagian besar ibu hamil kadang-kadang merasakan nyeri pinggang 46\%, sedangkan kadang-kadang juga merasakan nyeri punggung atas dan bawah $42,90 \%$, sebagian besar tidak pernah ada masalah pada gigi dan gusi $50.80 \%$, dan ketidaknyamanan yang lain kadang-kadang ibu hamil mudah lelah $46 \%$.

Tabel 4. Distribusi frekuensi Ketidaknyamanan Psikologis Kehamilan Trimester III

\begin{tabular}{clcc}
\hline No & \multicolumn{1}{c}{ Ketidaknyamanan Psikologis } & Jumlah $(\mathrm{n})$ & $\%$ \\
\hline 1 & Tidak Pernah & 7 & 11,10 \\
2 & Ringan & 17 & 27,00 \\
3 & Sedang & 29 & 46,00 \\
4 & Berat & 10 & 15,90 \\
\hline \multicolumn{2}{l}{ Total } & 63 & 100,00 \\
\hline Berdasarkan tabel 4 diketahui bahwa ketidaknyamanan psikologis ibu
\end{tabular}
hamil trimester III 46\% dalam kategori sedang.

Tabel 5. Distribusi frekuensi jenis ketidaknyamanan psikologis kehamilan trimester III

\begin{tabular}{clcc}
\hline No & \multicolumn{1}{c}{ Jenis Ketidaknyamanan } & Jumlah (n) & $\%$ \\
\hline 1 & Cemas Proses Persalinan & & \\
& Tidak Pernah & 14 & 22,20 \\
& Jarang & 16 & 25,40 \\
& Kadang-kadang & 26 & 41,30 \\
& Sering & 7 & 11,10 \\
Cemas kondisi bayi yang akan dilahirkan & 18 & 28,60 \\
& Tidak Pernah & 13 & 20,60 \\
& Jarang & 23 & 36,50 \\
& Kadang-kadang & 9 & 14,30 \\
Sering & & \\
Takut Nyeri Persalinan & 16 & 25,40 \\
& Tidak Pernah & 15 & 23,80 \\
& Jarang & 23 & 36,50 \\
& Kadang-kadang & 9 & 14,30 \\
\hline Sering & 63 & 100 \\
\hline
\end{tabular}

Berdasarkan tabel 5 diketahui bahwa ketidaknyamanan psikologi ibu hamil trimester III dilihat dari jenisnya adalah kadang-kadang ibu hamil cemas pada proses persalinan, cemas dengan kondisi janin yang akan dilahirkan dan takut nyeri saat persalinan dibawah $50 \%$. 
Sri Wulandari, Nonik Ayu Wantini (Ketidaknyamanan Fisik Dan Psikologis Pada Ibu Hamil Trimester III Di Wilayah Puskesmas Berbah Sleman Daerah Istimewa Yogyakarta)

Tabel 6. Distribusi frekuensi Kecemasan Kehamilan Trimester III akibat Pandemi Covid-19.

\begin{tabular}{|c|c|c|c|}
\hline No & Kecemasan & Jumlah (n) & $\%$ \\
\hline 1 & Tidak Pernah & 3 & 4,80 \\
\hline 2 & Ringan & 22 & 34,90 \\
\hline 3 & Sedang & 33 & 52,40 \\
\hline \multirow[t]{2}{*}{4} & Berat & 5 & 7,90 \\
\hline & Total & 63 & 100,00 \\
\hline
\end{tabular}

Berdasarkan tabel 6 diketahui bahwa kecemasan ibu hamil trimester III akibat pandemi Covid-19 52,40\% dalam kategori sedang

Tabel 7. Distribusi frekuensi jenis kecemasan akibat pandemi Covid-19 kehamilan trimester III.

\begin{tabular}{|c|c|c|c|}
\hline No & Jenis Kecemasan akibat pandemi Covid-19 & Jumlah (n) & $\%$ \\
\hline \multirow[t]{5}{*}{1} & Cemas pengaruh pandemi covid-19 terhadap kehamilan & & \\
\hline & Tidak Pernah & 9 & 14,30 \\
\hline & Jarang & 14 & 22,20 \\
\hline & Kadang-kadang & 28 & 44,40 \\
\hline & Sering & 12 & 19,00 \\
\hline \multirow[t]{5}{*}{2} & Bingung memilih tempat persalinan saat pandemi covid-19 & & \\
\hline & Tidak Pernah & 26 & 41,30 \\
\hline & Jarang & 8 & 12,70 \\
\hline & Kadang-kadang & 19 & 30,20 \\
\hline & Sering & 10 & 15,90 \\
\hline \multirow[t]{5}{*}{3} & Cemas biaya persalinan saat pandemi covid-19 & & \\
\hline & Tidak Pernah & 22 & 34,90 \\
\hline & Jarang & 17 & 27,00 \\
\hline & Kadang-kadang & 21 & 33,30 \\
\hline & Sering & 3 & 4,80 \\
\hline \multirow[t]{6}{*}{4} & Cemas saat ANC ke Faskes di masa pandemi covid-19 & & \\
\hline & Tidak Pernah & 19 & 30,20 \\
\hline & Jarang & 17 & 27,00 \\
\hline & Kadang-kadang & 23 & 36,50 \\
\hline & Sering & 4 & 6,30 \\
\hline & Total Responden & 63 & 100,00 \\
\hline
\end{tabular}

Berdasarkan tabel 7. Diketahui bahwa kecemasan ibu hamil trimester III akibat pandemi Covid-19 seperti kadang-kadang cemas pengaruh pandemi covid-19 terhadap persalinan dan cemas saat ANC ke Faskes di masa pandemi dibawah 50\%, sedangkan ibu tidak pernah bingung memilih tempat persalinan dan tidak pernah cemas tentang biaya persalinan juga di bawah $50 \%$. 
2. Analisis Bivariat

Tabel 8. Faktor karakteristik yang berhubungan dengan ketidaknyamanan psikologis kehamilan trimester III

\begin{tabular}{clcc}
\hline No & \multicolumn{1}{c}{ Variabel bebas } & p-value & Ket \\
\hline 1 & Status kehamilan & 0,141 & Tidak berhubungan \\
2 & Usia & 0,589 & Tidak berhubungan \\
3 & Pekerjaan & 0,702 & Tidak berhubungan \\
4 & Kebiasaan olahraga & 0,051 & Tidak berhubungan \\
5 & Pendidikan & 0,474 & Tidak berhubungan \\
6 & Jumlah janin & 0,285 & Tidak berhubungan \\
7 & Jumlah anak & $\mathbf{0 , 0 4 0}$ & Ada hubungan* \\
8 & Riwayat persalinan & 0,808 & Tidak berhubungan \\
9 & Riwayat komplikasi persalinan & 0,095 & Tidak berhubungan \\
\hline
\end{tabular}

Berdasarkan tabel 8 hasil analisis Kendal Tau diketahui dari faktor karakteristik yang berhubungan dengan ketidaknyamanan psikologis adalah jumlah anak dengan nilai $\mathrm{p}$-value $=0,040$ dimana nilai tersebut lebih kecil dari $\alpha=0,05$.

Tabel 9. Faktor karakteristik yang berhubungan dengan ketidaknyamanan fisik kehamilan trimester III.

\begin{tabular}{clcl}
\hline No & \multicolumn{1}{c}{ Variabel bebas } & p-value & Ket \\
\hline 1 & Status kehamilan & 0,896 & Tidak berhubungan \\
2 & Usia & 0,510 & Tidak berhubungan \\
3 & Pekerjaan & 0,107 & Tidak berhubungan \\
4 & Kebiasaan olahraga & 0,431 & Tidak berhubungan \\
\hline
\end{tabular}

Berdasarkan tabel 9 hasil analisis Kendal Tau diketahui bahwa dari faktor karakteristik tidak ada yang berhubungan dengan ketidaknyamanan fisik ibu hamil trimester III.

Tabel 10. Hubungan Jumlah anak dan ketidaknyamanan psikologi kehamilan trimester III

\begin{tabular}{|c|c|c|c|c|c|c|c|c|c|c|c|c|}
\hline \multirow{3}{*}{ No } & \multirow{3}{*}{$\begin{array}{l}\text { Jumlah } \\
\text { Anak }\end{array}$} & \multicolumn{8}{|c|}{ Ketidaknyamanan Psikologis } & \multirow{2}{*}{\multicolumn{2}{|c|}{ Total }} & \multirow{3}{*}{ p-value } \\
\hline & & \multicolumn{2}{|c|}{$\begin{array}{c}\text { Tidak } \\
\text { Pernah }\end{array}$} & \multicolumn{2}{|c|}{ Ringan } & \multicolumn{2}{|c|}{ Sedang } & \multicolumn{2}{|c|}{ Berat } & & & \\
\hline & & $\mathrm{n}$ & $\%$ & $\mathrm{n}$ & $\%$ & $\mathrm{n}$ & $\%$ & $\mathrm{n}$ & $\%$ & $\mathrm{n}$ & $\%$ & \\
\hline 1 & $2-4$ & 4 & 40 & 1 & 10 & 5 & 50 & 0 & 0 & 10 & 100 & \\
\hline 2 & 1 & 2 & 6,5 & 11 & 35,5 & 13 & 41,9 & 5 & 16,1 & 31 & 100 & $0,040 *$ \\
\hline 3 & 0 & 1 & 4,5 & 5 & 22,7 & 11 & 50 & 5 & 22,7 & 22 & 100 & \\
\hline \multicolumn{2}{|c|}{ Total } & 7 & 11,1 & 17 & 27 & 29 & 46 & 10 & 15,9 & 63 & 100 & \\
\hline
\end{tabular}

Berdasarkan tabel 10 diketahui bahwa ibu yang memiliki anak 2-4 50\% mengalami ketidaknyamanan psikologis sedang, dibandingkan dengan ibu yang mempunyai anak 1 atau belum pernah punya anak mengalami ketidaknyamanan berat $22,7 \%$. Hasil uji statistik Kendal Tau diketahui pvalue $=0,040$, dimana nilai tersebut lebih kecil dari $\alpha=0,05$ yang berarti ada hubungan yang signifikan antara jumlah anak dengan ketidaknyamanan psikologis ibu hamil trimester III di wilayah kerja Puskesmas Berbah Sleman Yogyakarta 
Tabel 11. Tabulasi silang ketidaknyamanan fisik dengan ketidaknyamanan psikologis pada ibu hamil trimester III

\begin{tabular}{|c|c|c|c|c|c|c|c|c|c|c|c|c|}
\hline \multirow{3}{*}{ No } & \multirow{3}{*}{$\begin{array}{c}\text { Ketidaknyamanan } \\
\text { Fisik }\end{array}$} & \multicolumn{8}{|c|}{ Ketidaknyamanan Psikologis } & \multirow{2}{*}{\multicolumn{2}{|c|}{ Total }} & \multirow{3}{*}{ p-value } \\
\hline & & \multicolumn{2}{|c|}{$\begin{array}{c}\text { Tidak } \\
\text { Pernah }\end{array}$} & \multicolumn{2}{|c|}{ Ringan } & \multicolumn{2}{|c|}{ Sedang } & \multicolumn{2}{|c|}{ Berat } & & & \\
\hline & & $\mathrm{n}$ & $\%$ & $\mathrm{n}$ & $\%$ & $\mathrm{n}$ & $\%$ & $\mathrm{n}$ & $\%$ & $\mathrm{n}$ & $\%$ & \\
\hline 1 & Ringan & 3 & 30 & 3 & 30 & 3 & 30 & 1 & 10 & 10 & 100 & \multirow{4}{*}{$0,012 *$} \\
\hline 2 & Sedang & 4 & 8,2 & 14 & 28,6 & 24 & 49 & 7 & 14,3 & 49 & 100 & \\
\hline \multirow[t]{2}{*}{3} & Berat & 0 & 0 & 0 & 0 & 2 & 50 & 2 & 50 & 4 & 100 & \\
\hline & Total & 7 & 11,1 & 17 & 27 & 29 & 46 & 10 & 15,9 & 63 & 100 & \\
\hline
\end{tabular}

Berdasarkan tabel 11 diketahui bahwa ibu hamil trimester III yang mengalami ketidaknyamanan fisik ringan 30\% tidak pernah mengalami ketidaknyamanan psikologis, sedangkan ibu hamil mengalami ketidaknyamanan fisik berat $50 \%$ juga mengalami ketidaknyamanan psikologis. Hasil uji statistik Kendal Tau di ketahui p-value $=0,012$, dimana nilai tersebut lebih kecil dari $\alpha=0,05$ yang berarti ada hubungan yang signifikan antara ketidaknyamanan fisik dengan ketidaknyamanan psikologis

Tabel 12. Tabulasi silang ketidaknyamanan fisik dengan kecemasan akibat Covid19 ibu hamil trimester III.

\begin{tabular}{|c|c|c|c|c|c|c|c|c|c|c|c|c|}
\hline \multirow{3}{*}{ No } & \multirow{3}{*}{$\begin{array}{l}\text { Ketidaknya } \\
\text { manan fisik }\end{array}$} & \multicolumn{8}{|c|}{ Kecemasan akibat pandemi Covid-19 } & \multirow{2}{*}{\multicolumn{2}{|c|}{ Total }} & \\
\hline & & \multicolumn{2}{|c|}{$\begin{array}{l}\text { Tidak } \\
\text { Pernah }\end{array}$} & \multicolumn{2}{|c|}{ Ringan } & \multicolumn{2}{|c|}{ Sedang } & \multicolumn{2}{|c|}{ Berat } & & & \multirow[t]{2}{*}{-value } \\
\hline & & $\mathrm{n}$ & $\%$ & $\mathrm{n}$ & $\%$ & $\mathrm{n}$ & $\%$ & $\mathrm{n}$ & $\%$ & $\mathrm{n}$ & $\%$ & \\
\hline 1 & Ringan & 0 & 0 & 7 & 70 & 3 & 30 & 0 & 0 & 10 & 100 & \multirow{4}{*}{$0,013^{*}$} \\
\hline 2 & Sedang & 3 & 6,1 & 15 & 30,6 & 27 & 55,1 & 4 & 8,2 & 49 & 100 & \\
\hline \multirow[t]{2}{*}{3} & Berat & 0 & 0 & 0 & 0 & 3 & 75 & 1 & 25 & 4 & 100 & \\
\hline & Total & 3 & 4,8 & 22 & 34,9 & 33 & 52,4 & 5 & 7,9 & 63 & 100 & \\
\hline
\end{tabular}

Berdasarkan tabel 12 diketahui bahwa 55,1\% ibu hamil trimester III yang mengalami ketidaknyamanan fisik sedang, mengalami kecemasan sedang akibat Covid-19. Sedangkan ibu yang mengalami ketidaknyamanan fisik berat, 25\% mengalami kecemasan akibat pandemi Covid-19 yang berat. Hasil uji statistik Kendal Tau di ketahui p-value $=0,013$, dimana nilai tersebut lebih kecil dari $\alpha=0,05$ yang berarti ada hubungan yang signifikan antara kecemasan akibat Covid-19 dengan ketidanyamanan fisik ibu hamil trimester III di wilayah kerja Puskesmas Berbah Sleman Yogyakrta

\section{Pembahasan}

1. Karakteristik Responden

Usia responden mayoritas adalah usia reproduktif (20-35 tahun) 84,10\%, usia untuk hamil dan melahirkan paling baik adalah usia 20-35 tahun. Sesuai dengan penelitian (Sukorini MU, 2017)83,33\% responden berusia 20-35 tahun, karena pada usia ini merupakan usia ideal sehingga dianggap memiliki resiko paling rendah terjadinya komplikasi (Rasjidi, 2014). Tabel 1 juga menunjukan bahwah sebagian besar responden berpendidikan perguruan tinggi $(46 \%)$ dan bekerja $(52,40 \%)$. Makin tinggi tingkat pendidikan 
seseorang, maka makin mudah dalam memperoleh dan menerima informasi, sehingga kemampuan ibu dalam berpikir lebih rasional. (Walyani E.S, 2015) Begitu juga dengan ibu yang bekerja, bahwa motivasi ibu bekerja adalah untuk menambah penghasilan keluarga, menghindari rasa bosan, mengisi waktu luang, dan ingin mengembangkan diri.Selama kehamilan tidak ada larangan bagi seorang ibu hamil untuk bekerja diluar rumah. Hasil penelitian ini bahwa responden sebagian besar multigravida $(65,10 \%)$, sejalan dengan hasil peneltian (Elheart B dkk, 2017) 54\% responden mempunyai paritas multipara Paritas 2-3 merupakan paritas paling aman ditinjau dari sudut kematian maternal.

2. Ketidaknyamanan fisik kehamilan trimester III

Ibu hamil trimester III dapat terjadi perubahan fisik yang dapat menimbulkan ketidaknyamanan selama kehamilan seperti timbul masalah pada saluran pencernaan, kelelahan, bengkak pada kaki, sesak nafas, sensitifitas kandung kemih dan nyeri punggung (Neil W, 2007) . Ketidaknyamanan fisik yang dirasakan ibu ini umumnya akan semakin bertambah seiring dengan bertambahnya umur kehamilan (Aprillia Y, 2014). Tabel 2 hasil penelitian menunjukan bahwa $77,80 \%$ responden mengalami ketidaknyamanan fisik sedang, yang artinya gangguan kenyamanan fisik yang dirasakan ibu hamil tidak mengganggu aktivitas sehari-hari ibu hamil seperti bekerja, tidur dan lain-lain. Adapun jenis ketidaknyamanan fisik sering dialami ibu sering BAK $73 \%$, kemudian yang lain nyeri pinggang, nyeri punggung atas bawah, susah tidur, kram pada kaki di bawah 50\%, sedang yang lainnya jarang dirasakan ibu bahkan tidak pernah. Menurut tabel 9 didapatkan hasil bahwa karakteristik seperti usia, pekerjaan, kehamilan dan kebiasaan olah raga tidak berhubungan dengan ketidaknyamanan fisik ibu hamil trimester III.

3. Ketidaknyamanan Psikologis Kehamilan Trimester III

Berdasarkan tabel 4 hasil penelitian menunjukan bahwa responden mengalami ketidaknyamanan psikologis 46\% kategori sedang, penelitian ini sejalan dengan penelitian (Fazdria, Harahap MS, 2016) mayoritas memiliki gejala tingkat kecemasan (psikologis) sedang 48\%. Adapun jenis ketidaknyamanan psikologis yang kadang-kadang dialami responden seperti cemas proses persalinan 41,30\%, cemas dengan kondisi bayi yang akan dilahirkan dan takut nyeri persalin sebesar 36,50\%. Sedangkan dari faktor karakteristik seperti usia, pekerjaan, kebiasaan olahraga, pendidikan, jumlah janin, riwayat persalinan dan riwayat komplikasi persalinan tidak mempunyai hubungan dengan ketidaknyamanan psikologis ibu hamil terimester III. Adapun penyebab lain ketidaknyamana psikologis antara lain timbul akibat melihat bahaya yang mengancam dirinya. rasa takut, karena sumbernya terlihat jelas di dalam pikiran. Pikiran negative ibu tentang sesuatu yang akan terjadi pada saat nanti persalinannya membuat ibu merasa cemas (Rochman, 2010). Menurut penelitian yang dilakukan oleh (Reska, 2012) Hasil analisis data menggunakan uji statistik Kendal Tau diperoleh hasil p-value 0,012 < 0,05, 
hal ini membuktikan bahwa ada hubungan yang signifikan antara ketidaknyamanan fisik dengan ketidaknyamanan psikologi ibu hamil trimester III penelitian ini sejalan dengan penelitian (Sukorini MU, 2017) gangguan kenyamanan fisik terdapat nilai kekuatan hubungan yang menunjukkan nilai 0,363 yang artinya terdapat hubungan rendah antara gangguan kenyamanan fisik dan kualitas tidur ibu hamil trimester III. Semakin berat ketidaknyamanan fisik yang dialami oleh ibu hamil, semakin berat pula ketidaknyamanan psikologis yang dialami oleh ibu hamil. Sedangkan hasil analisis data jumlah anak menggunakan uji statistik Kendal Tau diperoleh hasil p-value $0,040<0,05$, hal ini membuktikan bahwa ada hubungan yang signifikan antara jumlah anak dengan ketidaknyamanan psikologi ibu hamil trimester III. Penelitian ini sejalan dengan (Heriani, 2016) menunjukkan bahwa ada hubungan yang bermakna antara paritas ibu dengan tingkat kecemasan dalam menghadapi masa menjelang persalinan dengan $\mathrm{p}$ value 0,008. Semakin banyak anak, ketidaknyamanan psikologis yang dirasakan semakin ringan. Belum memiliki anak (belum pernah melahirkan), ketidaknyamanan psikologis yang dirasakan semakin berat. Faktor yang mempengaruhi kecemasan ibu hamil menghadapi persalinan antara lain dukungan keluarga. Dengan dukungan informasi yang diberikan dengan cara memberikan pengetahuan dan informasi tentang kehamilan serta persiapan persalinan yang baik, kecemasan ibu tentang hal-hal negatif yang dipikirkannya akan berkurang.

4. Kecemasan akibat pandemi Covid-19 kehamilan trimester III

Sebagian besar studi yang telah dilakukan tentang COVID-19 dan keterkaitannya terhadap kehamilan berfokus pada efek fisik pandemi pada ibu yang terinfeksi serta kemungkinan penularannya. Walaupun belum banyak bukti yang menunjukkan bahwa COVID-19 dapat berdampak pada wanita hamil ataupun janin dalam kandungan, namun penting untuk tidak mengabaikan keterlibatan emosi wanita hamil selama pandemi COVID-19 karena kesehatan mental ibu dapat dikaitkan dengan risiko jangka pendek dan jangka panjang bagi mereka ataupun bagi anak-anaknya, baik kesehatan fisik maupun kesehatan psikologis (Kotabagi P dkk, 2020). Hasil penelitian menunjukan bahwa ibu hamil trimester III yang mengalami kecemasan akibat pandemi Covid-19 sebesar 52,40\% kategori sedang. Jenis kecemasan yang di rasakan ibu yaitu pengaruh virus terhadap kehamilan dan memilih tempat periksa ANC saat pandemi semua di bawah 50\%. Penelitian ini tidak sejalan dengan peneltian (Muhamad DT, 2020).Adanya peningkatan kecemasan pada wanita hamil pada masa pandemi COVID-19. Kondisi kehamilan menyebabkan penurunan kekebalan parsial karena perubahan fisiologi pada saat kehamilan, sehingga mengakibatkan ibu hamil lebih rentan terhadap infeksi virus. Oleh karena itu, pandemi COVID-19 sangat mungkin menyebabkan konsekuensi yang serius bagi ibu hamil (28-30) (Anung AP dkk, 2020). Berdasarkan hasil analisis data menggunakan uji statistik Kendal Tau diperoleh hasil p-value 0,013 < 0,05, hal ini membuktikan bahwa ada 
hubungan yang signifikan antara ketidaknyamanan fisik dengan kecemasan akibat Covid-19. Semakin berat ketidaknyamanan fisik yang dialami oleh ibu hamil, semakin berat pula kecemasan akibat pandemi covid 19 yang dialami oleh ibu hamil. Faktor lainnya yang memengaruhi tingkat kecemasan ini adalah ada tidaknya dukungan dari keluarga serta tenaga perawat dalam membantu mengurangi persepsi risikonya yang dalam menimbulkan kecemasan

\section{Simpulan}

\section{SIMPULAN DAN SARAN}

Berdasarkan hasil penelitian ada hubungan antara jumlah anak dengan ketidaknyamanan psikologi, ada hubungan antara ketidaknyamanan fisik dengan ketidaknyamanan psikologis serta ada hubungan kecemasan akibat covid 19 dengan ketidaknyamanan fisik pada ibu hamil trimester III di wilayah kerja Puskesmas Berbah Sleman Yogyakarta. Adapun jenis ketidaknyamanan fisik yang sering dialami ibu hamil trimester III adalah buang air kecil, kadang-kadang ibu juga merasakan kram pada kaki, susah tidur, nyeri pinggang, nyeri punggung atas bawah, dan mudah lelah. Ketidaknyamanan psikologis yang kadang-kadang juga dialami ibuhamil adalah cemas saat proses persalinan, cemas kondisi bayai yang akan dilahirkan serta takut nyeri saat persalinan. Sedangkan masa pandemi berdampak pada kecemasan ibu hamil seperti cemas pengaruh Covid-19 terhadap janin, ibu cemas untuk periksa ANC ke fasilitas kesehatan dimasa pandemi

\section{Saran}

Institusi pendidikan UNRIYO bekerjasama dengan Puskesmas Berbah dalam kegiatan pengabdian kepada masyarakat, dengan cara membantu memberikan edukasi kepada masyarakat khususnya ibu hamil tentang perubahan fisik dan psikologis selama kehamilan serta rutin memberikan pelatihan senam hamil atau Yoga pad ibu hamil untuk mengurangi keluhan ketidak nyamanan fisik selama hamil serta memberikan informasi yang lengkap tentang Covid-19 agar ibu tidak cemas untuk tetap periksa ANC di fasilitas kesehatan. Kegiatan dilaksanakan secara rutin setiap bulannya melalui kelas ibu hamil yang sudah menjadi program Puskesmas.

\section{DAFTAR PUSTAKA}

Andarmoyo, S. 2013. Konsep dan Proses Keperawatan Nyeri. Yogyakarta: ArRuzz Media

Anung Ahadi Pradana, dkk, 2020. Pengaruh Kebijakan Social Distancing Pada Wabah Covid-19 Terhadap Kelompok Rentan Di Indonesia, Jurnal Kebijakan Kesehatan Indonesia : JKKI, Vol. 09, No. 02 Juni 2

Aprilia, Y. 2014. Diary Ibu Hamil. Jakarta: Kawan Pustaka

Elheart Budiman, dkk, 2017. Hubungan Tingkat Pendidikan, Pekerjaan, Status Ekonomi Dengan Paritas Di Puskesmas Bahu Manado, e-Journal Keperawatan(e-Kp) Volume 5 Nomor 1, Februari 2017. 
Emi Nurjasmi. 2020. Situasi Pelayanan Kebidanan pada Masa Pandemi Covid19, Webinar IDM 5 May 2020, https://www.ibi.or.id/media/Webinar\%20IDM\%202020/IBI\%20$\% 203 \% 20$ Situasi\%20Pelayanan\%20Kebidanan\%20di\%20Masa\%20Pade mic\%20Covid-19-compressed.pdf, diakses 1 Januari 2021

Fauziah, Lestari. 2017. Efektifitas Latihan Yoga Prenatal dalam menurunkan Kecemasan pada Ibu Primigravida Trimester III. Universitas Padjajaran. http://pustaka.unpad.ac.id/wp-content/uploads/2016/04/LestariFauziah.pdf.

Fazdria dan Meliani Sukmadewi Harahap, 2016. Gambaran Tingkat Kecemasan Pada Ibu Hamil Dalam Menghadapi Persalinan Di Desa Tualang Teungoh Kecamatan Langsa Kota Kabupaten Kota Langsa, Jurnal Kedokteran Syiah Kuala Volume 16 Nomor 1 April 2016

Fitriani. 2018. Efektifitas Senam Hamil dan Yoga Hamil terhadap Penurunan Nyeri Punggung pada Ibu Hamil TM III di Puskesmaas Pekkabata. J. Kesmas Vol 4 No 2, September 2018

Handayani, R. (2012). Faktor-Faktor yang Berhubungan dengan Tingkat Kecemasan Menjelang Persalinan Pada Ibu Primigravida Trimester III di Wilayah Kerja Puskesmas Lubuk Buaya Padang Tahun 2012. Jurnal Keperawatan. 11(1). Maret 2015:62-71

Intarti. 2017. Kontribusi Senam Ibu Hamil TM III dalam Pengurangan Nyeri Punggung di wilayah Ekskotatif Cilacap. Bidan Prada: Jurnal Ilmiah Kebidanan, Vol 8 No. 1 edisi Juni 2017

Kholil Lur Rochman. (2010). Kesehatan Mental. Purwokerto: Fajar Media Press

Kusmiyati. 2010. Asuhan Kebidanan. Yogyakarta: Tritama

Mariyam Ulfa Sukorini, 2017. Hubungan Gangguan Kenyamanan Fisik Dan Penyakit Dengan Kualitas Tidur Ibu Hamil Trimester III, The Indonesian Journal of Public Health, Vol. 12 No. 1, Juli 2017: 1-12

Neil, W. 2007. Panduan Lengkap Perawatan Kehamilan. Jakarta: Dian Rakyat Prawirohardjo. 2017. Ilmu Kebidanan. Jakarta: PT Bina Pustaka

Rasjidi, I. 2014. Panduan Kehamilan Muslimah. Jakarta: PT. Mizan Republika Rosdiani, dkk. 2014. Posisi Tidur Miring Efektif Menurunkan Nyeri Punggung Pada Ibu Hamil Trimester III di Poli KIA RS Rahman Rahim Desa Saimbang Sukodoo Sidoarjo. Jurnal Ilmiah Kesehatan. Vol 7 Nomor 2 hal 81-87

Saifuddin. 2008. Pelayanan Kesehatan Maternal Neonatal. Jakarta Bina Pustaka Walyani E.S. 2015. Asuhan Kebidanan Pada Kehamilan, PUSTAKABARUPRESS, Yogyakarta 